УДК 347.626 .96

DOI https://doi.org/10.32849/2663-5313/2020.12.06

\title{
Лілія Радиенко,
}

канд. юрид. наук, дочент,

дочент кафедри цивільного права

Інституту права

Київського начіонального університету імені Тараса Шевченка

\section{СІМЕЙНІ ТРАСТИ Й УПРАВЛІННЯ МАЙНОМ ПОДРУЖЖЯ В ПРАВІ ОКРЕМИХ ІНОЗЕМНИХ ДЕРЖАВ}

Стаття присвячена розгляду особливостей регулювання відносин щодо управління майном подружжя за законодавством різних держав і правових сімей, визначенню спеиифіки нормативного закріплення та реалізації прав подружжя на управління спільним майном у праві окремих іноземних держав, а також окресленню основних правових підходів зарубіжних законодавств із ивого приводу. На підставі проведеного дослідження сформульовано висновки та пропозицї щодо вдосконалення и розвитку начіональної системи правового регулювання сімейних відносин.

У статті на підставі порівняльно-правового аналізу положень нормативно-правових актів іноземних держав у сфері регулювання відносин шодо управління майном подружжя наголошується про наявність декількох правових підходів. Згідно з першим, який застосовується насамперед у країнах континентальної правової сім'ї, управління майном подружжя здійснюється на базі легального режиму, що передбачає спільне управління подружнім майном (із певними особливостями, визначеними начіональним законодавством відповідних держав), якщо інше не передбачено договором між ними. У державах Азії правове регулювання відносин щодо управління майном подружжя врегульовано по-різному, проте навіть сьогодні для сімейного права багатьох держав иього регіону характерним $\epsilon$ неформальне верховенство чоловіка у вирішенні питання щодо управління спільним майном. Відповідно до підходу, що застосовується в країнах англо-американської правової сім'ї, управління майном подружжя базується на системі сімейних трастів, що передбачає можливість надання спільного майна в управління третій особі на користь подружжя чи ӥхніх дітей.

У сімейному законодавстві України домінуючим є перший підхід, що передбачає управління майном подружжя на базі легального режиму. Проте не варто беззастережно заперечувати можливість застосування елементів довірчого управління для регламентаиї̈ відносин щодо набуття й управління спільним майном подружжя. Реалізачія інституту довірчого управління в сімейних відносинах має не суперечити законодавству Украйни, принципам сімейного права та моральним засадам суспільства, а також задовольняти права й законні інтереси подружжя в управлінні спільним майном.

Ключові слова: спільне майно, легальний режим, договірний режим, сім'я, сімейні відносини, довірче управління, сімейний траст, міжнародне сімейне право.

Постановка проблеми. Категорії «управління майном», «довірче управління майном» $\mathrm{i}$ «траст» можна досліджувати не лише як «атрибути» сфери цивільного права, а й через особливу призму правовідносин сімейних, а саме шлюбно-сімейних відносин. Прояви цих конструкцій убачаємо й у сфері сімейного права. Твердженням цьому може слугувати аналіз положень сімейного законодавства багатьох держав, на нормах окремих із яких зупинимося нижче.

Загальноприйнятим є підхід, що визначає довірче управління як цивільно-правові відносини, які виникають між довірителем і довіреною особою щодо здійснення довірчих операцій з об'єктом довірчого управління від імені, за рахунок та в інтересах довірителя [1, с. 229]. Ризики випадкової загибелі майна, а також ризики можливих збитків від довірчого управління майном несе довірена особа. Водночас буквальне тлумачення слова «довірчий» означає той, який виявляє, виражає довіру чому-небудь і грунтується на довірі. На наше переконання, саме міцні шлюбні відносини є тими відносинами, які виникають, будуються та базуються на довірі. Ця обставина пояснює факт існування в системі положень законодавства різних держав у сфері сімейно-шлюбних відносин норм, присвячених управлінню майном.

Зазначене зумовлює актуальність проведення правового дослідження регламентації відносин щодо управління майном подружжя за законодавством окремих іноземних держав. 
Метою статті є дослідження особливостей регулювання відносин щодо управління майном подружжя за законодавством різних держав і правових сімей, визначення специфіки нормативного закріплення та реалізації прав подружжя на управління спільним майном у праві окремих іноземних держав, окреслення основних правових підходів у зазначеній сфері, а також формулювання висновків і пропозицій щодо вдосконалення та розвитку національної системи правового регулювання сімейних відносин.

Розгляд особливостей управління майном подружжя через призму міжнародного приватного права був предметом наукового дослідження вітчизняних науковців, зокрема T.В. Боднар, А.С. Довгерта, О.В. Дзери, B.I. Кисіля, Р.А. Майданика та інших учених, а також представників правової доктрини іноземних держав.

Виклад основного матеріалу. Правове регулювання майнових відносин подружжя у міжнародному сімейному праві може встановлювати договірний або легальний правовий режим майна подружжя. Так, договірний правовий режим майна подружжя виникає внаслідок укладення подружжям шлюбного договору. Коли подружжя не укладають шлюбного договору, їхні майнові відносини підпорядковуються приписам закону; відтак установлюється легальний правовий режим майна подружжя [2, с. 489-490].

Правовий режим майна подружжя є своєрідною підставою для управління майном. Порядок управління майном подружжя нині побудовано внаслідок суттєвих історичних реформ сімейного права, зокрема визнання заміжньої жінки дієздатною. Проте навіть сьогодні для сімейного права окремих держав характерним $є$ верховенство чоловіка, оскільки в багатьох країнах до сьогодні зберігається нерівноправне становище чоловіка і дружини в сім'ї. Цивільні кодекси таких держав передбачають, що шлюбний договір укладається до шлюбу й закріплює насамперед права чоловіка на майно дружини, тобто мова йде про збереження за чоловіком, хоча й у звуженому вигляді, певних переваг в управлінні майном і вирішенні матеріальних питань шлюбу. Так, наприклад, як зазначено в літературі [3], ці переваги продовжують зберігатися й понині в Аргентині, Бразилії, Іспанії, де чоловік вирішує основні питання управління майном.

Право Франції передбачає можливість одноосібного управління спільним майном подружжя, але 3 певними особливостями; чоловік здійснює управління загальною час- тиною майна, але найбільш важливі угоди він може вчиняти тільки за згодою дружини, а дружина управляє своєю (резервною) частиною майна, що набута нею на свою заробітну плату.

Загалом Цивільним кодексом (далі - ЦК) Французької Республіки (Code Civil des Français) передбачено чотири можливі режими майна подружжя: режим спільного володіння майном, спільно набутим у шлюбі; режим роздільного володіння майном; режим участі у володінні майном, спільно набутим у шлюбі; режим спільного володіння майном. Перший режим майна подружжя є легальним і встановлюється автоматично на підставі самого факту укладення шлюбу. Якщо подружжя вибирає один із трьох інших режимів майна подружжя, то необхідне укладення шлюбного договору, у якому закріплюється цей режим. Такий договір укладається в нотаріуса найчастіше до укладення шлюбу.

Також у ч. 1 ст. 214 ЦК Французької Республіки передбачено, що, якщо шлюбні домовленості не визначають внесок подружжя до бюджету сім'ї, обоє з подружжя роблять цей внесок відповідно до їхніх можливостей, і цей обов'язок, як й особисті немайнові відносини між подружжям, виникає на основі юридичного факту реєстрації шлюбу [4]. У ЦК Франції визначено, що один із подружжя не може без згоди іншого розпоряджатися правами, що стосується оселі сім'ї та предметів її обстановки. Той із подружжя, який не дав своєї згоди на здійснення такої угоди, має право вимагати ії анулювання; позов про анулювання угоди може бути заявлено протягом року, наступного за днем, коли подружжя дізналося про цю угоду, але ні в якому разі не пізніше року після припинення майнових відносин між подружжям (ст. 215) [4].

Натомість законодавство інших держав обмежує можливість одноосібного управління подружнім майном. При цьому найбільш важливі для подружжя правочини мають здійснюватися за взаємною згодою обох із подружжя, хоча вони наділені рівними правами щодо управління майном.

Найбільш яскравим прикладом такого легального підходу до вирішення питань позбавлення одноособовим правом щодо управління майном подружжя є законодавство Німеччини. Зокрема, положення Німецького цивільного уложення (Bürgerliches Gesetzbuch, BGB) містять такі правила. Так, кожний із подружжя має право здійснювати угоди, необхідні для забезпечення життєвих потреб сім'ї, у тому числі й в інтересах іншого подружжя. Права й обов’язки за такими уго- 
дами набувають обидва з подружжя, за винятком випадків, якщо інше не випливає з обставин справи (пп. (1) (2) § 1357). Загалом кожний із подружжя має право самостійно розпорядитися своїм майном, але з певними межами (§ 1364). Так, подружжя може взяти на себе зобов'язання щодо розпорядження своїм майном загалом лише за згодою іншого подружжя [5].

Під час існування шлюбного союзу у Швейцарії, згідно зі ст. 163 ЦК (Code civil Suisse; Schweizerisches Zivilgesetzbuch) [6], чоловік і дружина сприяють, кожен згідно з їхніми можливостями, належному забезпеченню сім'ї. Другий параграф уточнює, що чоловік і жінка домовляються про спосіб, яким кожен робить свій внесок, у тому числі грошима, домашньою роботою, доглядом за дітьми або допомогою подружжю в його професії або діяльності. Крім того, подружжя враховують потреби сімейного союзу та їхню особисту ситуацію.

Згідно зі ст. 164 ЦК, подружжя, яке займається домашнім господарством, дітьми або допомагає у веденні діяльності другого 3 подружжя, має право отримувати регулярно справедливу грошову суму, якою може вільно розпоряджатися. При визначенні цієї справедливої суми необхідно враховувати власні доходи подружжя-кредитора, а також зобов’язання подружжя-боржника перед сім'єю.

При цьому варто зазначити, що на подружжя поширюється режим подружньої власності за умови, що вони не домовилися про інше в шлюбному договорі, і за умови, що не набрав чинності надзвичайний режим майнового шлюбу (ст. 171 ЦК) [6]. Режим подружнього майна включає майно, придбане під час шлюбу, та індивідуальне майно кожного з подружжя. Придбане майно включає ті активи, які подружжя придбало за час перебування в шлюбі.

У державах Азії правове регулювання відносин щодо управління майном подружжя врегульовано по-різному, проте навіть сьогодні для сімейного права багатьох держав цього регіону характерним є неформальне верховенство чоловіка у вирішенні питання щодо управління спільним майном.

У Китаї, відповідно до тлумачення Верховного Суду КНР «Про деякі питання застосування Закону про шлюб КНР» від 2001 р. № 1, ст. 17 Закону, що передбачає рівні права чоловіка і дружини на розпорядження спільною власністю, варто розуміти так: (1) чоловік і дружина мають рівні права розпоряджатися їхньою спільною власністю. Якщо треба розпорядитися їхньою спільною власністю для задоволення щоденних потреб, як чоловік, так і дружина мають право приймати рішення; і (2) коли чоловік або дружина повинні прийняти важливе рішення щодо розпорядження їхньою спільною власністю для задоволення щоденних потреб, чоловік і дружина повинні обговорювати це на рівноправній основі з тим, щоб досягти угоди [7].

У ЦК Турецької Республіки [8] передбачені законний режим майна та договірний режим майна. Стосовно законного режиму, то майно подружжя може перебувати в «режимі майнового союзу». Відповідно до ст. 256 ЦК Турецької Республіки, режим «майнового союзу» охоплює майно «союзу» та особисте майно подружжя. Подружжя володіє таким майном як нерозділене ціле. Кожен із подружжя має право управляти, користуватися та розпоряджатися майном у законних межах. Один із подружжя не може розпоряджатися своєю часткою в майні, що перебуває в спільній власності, без згоди іншого, якщо про інше не домовлено між ними (ст. 223) [8]. Кожен із подружжя відповідає за свої борги всіма своїми активами.

Кожен із подружжя має подружнє право на майно другого 3 подружжя (ст. 35) Один із подружжя може дозволити іншому 3 подружжя управляти майном першого з подружжя, останній у такому випадку має право використовувати доходи від власності на утримання сім'ї без необхідності звітності. Майно, яке не використалося в інтересах сім'ї, передається власнику.

У законодавстві Ісламської Республіки Іран діє принцип, який визначає, що чоловік є главою сім'ї, що закріплений у статті 1105 ЦК Ірану [9].

Норми статей 1106-1109 ЦК Ірану передбачають зобов'язання чоловіка надавати дружині утримання та сутність такого утримання. Відповідно до ст. 1106 ЦК Ірану, витрати на утримання дружини в постійному шлюбі (оскільки, за законодавством Ірану, передбачений також тимчасовий шлюб) покладаються на чоловіка. Вартість такого утримання включає вартість одягу, їжі, житла, меблів залежно від статусу дружини, на розумній основі, надання служниці, якщо дружина звикла мати слуг або якщо вони їй потрібні через хворобу або стан здоров'я, вартість медичного лікування. Право на утримання дружини набуває чинності в момент укладення шлюбу й залишається чинним упродовж усього терміну шлюбу, якщо дружина не перебуває в стані «непослуху».

Як зазначає іранський дослідник Ехсан Зар Рох, дружина не втрачає право на утримання, навіть якщо чоловік збіднів, у дружини є своє окреме майно [10]. Не існує 
жодного зобов'язання щодо фінансової допомоги, утримання дружиною чоловіка. Шлюби базуються на принципі, згідно з яким відповідальність за фінансовий добробут сім'ї повністю покладається на чоловіка.

У країнах англо-американської правової системи для управління майном подружжя застосується інститут сімейного трасту.

В Індії управління сімейним майном може здійснюватися із застосуванням інституту довірчої власності або трасту, що існуе відповідно до положень Закону Індії «Про трасти» 1882 року. Під трастом, відповідно до ст. 3 цього Закону, в Індії розуміється зобов'язання, приєднане до права власності на майно, що виникає внаслідок довіри, і при якому власник передає майно в довірчу власність управителю, який буде здійснювати управління цим майном і в інтересах вигодонабувача [11].

Створення трасту цілком можливе 3 метою управління сімейним майном, хоча ця практика не $є$ поширеною серед середньостатистичного індійського населення. Загалом сімейний траст в Індії - це своєрідний довірчий фонд, створений на користь осіб, споріднених між собою кровними або законними відносинами. Він може бути встановлений членом сім'ї на благо членів сімейної групи. Сімейні трасти є інструментом передачі майна майбутнім поколінням. Сімейний траст також може бути використаний для забезпечення конкретних потреб сім'ї, скажімо, освіти, або охорони здоров'я, або подорожей, чи одруження, і сам по собі виступае як правовий засіб, який зберігає активи лише для цієї конкретної мети, примножуючи, охороняючи, управляючи та забезпечуючи іх для цієї конкретної мети [12].

У США здійснення управління сімейним майном на підставі категорії довірчої власності або ж трасту є досить поширеним явищем і широко використовується. Узагалі траст як правова конструкція виник у системі загального права, до якої належать і США. У США є єдиний статутний кодекс для п'ятдесяти штатів, який називається Єдиний трастовий кодекс (UTC). Нині більшість штатів прийняла цей нормативноправовий акт, в інших він перебуває на розгляді [13].

Сімейні трасти в США - це довірчі відносини, на які погоджуються дві або більше сторін. Особа-установник трасту надає іншій стороні, яка називається довіреною особою, право мати право власності на майно сім'ї на користь визначених установником трасту бенефіціаріїв.

У США траст може бути відкличним і безвідкличним. При відкличному трасті установник може змінити свої умови. Сімейні трасти - це, як правило, відкличні трасти. Умови трасту й точні активи, що входять до трастового майна, можуть бути змінені в будь-який час. Це справедливо для всіх значних закупівель і продажів матеріального майна (будинків, транспортних засобів тощо) та нематеріальних активів (цінних паперів та інших фінансових інвестицій). Подібним чином установник трасту може в будь-який час змінити повірену особу та бенефеціаріїв [14].

Ідея сімейного трасту полягає в захисті права власності на сімейні активи 1 забезпечення інтересів членів сім'ї. На підставі трасту відбувається передача законного права власності на сімейні активи довіреним особам, хоча користування ними може продовжуватися, доки це дозволяє довірчий акт. Наприклад, якщо спільний будинок сім'ї знаходиться в довірчому управлінні, сім'я більше не має власного будинку, але вона все одно може жити в ньому, якщо про це йдеться в трастовому договорі.

Переваги сімейного трасту: сімейні трасти призначені для захисту активів і вигоди для членів сім'ї. Коли активи перебувають у сімейному трасті, активи належать повіреним особам, які здійснюють управління ними на благо визначених членів сім'ї; сімейний траст забезпечує захист активів від вимог кредиторів, наприклад, для захисту сімейного будинку від потенційного банкрутства комерційного підприємства; сімейний траст дозволяє відкласти гроші для особливих причин, наприклад, навчання дитини; сімейний траст дозволяє зберегти спадщину окремо для дітей установника трасту, а не для їхніх партнерів [15].

\section{Висновки}

На підставі проведеного порівняльноправового аналізу положень нормативноправових актів окремих зарубіжних держав про управління майном подружжя можна констатувати наявність декількох правових підходів.

Згідно з першим, який застосовується насамперед у країнах континентальної правової сім'ї, управління майном подружжя здійснюється на базі легального режиму, що передбачає спільне управління подружнім майном (із певними особливостями, визначеними національним законодавством відповідних держав), якщо інше не передбачено договором між ними.

У державах Азії правове регулювання відносин щодо управління майном подружжя врегульовано по-різному, проте навіть сьогодні для сімейного права багатьох держав 
цього регіону характерним є неформальне верховенство чоловіка у вирішенні питання щодо управління спільним майном.

Відповідно до підходу, що застосовується в країнах англо-американської правової сім'ї, управління майном подружжя базується на системі сімейних трастів, що передбачає можливість надання спільного майна в управління третій особі на користь подружжя чи їхніх дітей.

У сімейному законодавстві України домінуючим є перший підхід, що передбачає управління майном подружжя на базі легального режиму. Проте не варто беззастережно заперечувати можливість застосування елементів довірчого управління для регламентації відносин щодо набуття й управління спільним майном подружжя. Реалізація інституту довірчого управління в сімейних відносинах має не суперечити законодавству України, принципам сімейного права та моральним засадам суспільства, а також задовольняти права й законні інтереси подружжя в управлінні спільним майном.

\section{Список використаних джерел:}

1. Довірче управління майном. Юридична енииклопедія : у 6 т. / ред. кол. Ю.С. Шемшученко (відп. ред.) та ін. Київ : Українська енциклопедія, 1998. Т. 2.744 c.

2. Сімейне право України : підручник / за заг. ред. Т.В. Боднар та О.В. Дзери. Київ : Юрінком Інтер, 2016. $520 \mathrm{c}$.

3. Гражданское и торговое право зарубежных государств : учебник : в 2 т. / отв. ред. Е.А. Васильев, А.С. Комаров. 4-е изд., перераб. и доп. Москва : Междунар. отношения, 2008. T. II. C. $540-541$

4. Civil code. URL: https://www.legifrance. gouv.fr/codes/texte_lc/LEGITEXT00000607072 (дата звернення: 03.12.2020).

5. Bürgerliches Gesetzbuch. URL: https:// www.gesetze-im-internet.de/bgb/ (дата звернення: 03.12.2020).
6. Swiss Civil Code of 10 December 1907 URL: https://www.admin.ch/opc/en/classifiedcompilation/19070042/index.html (дата звернення: 03.12.2020).

7. Беликова К.М. Роль судебных Толкований в развитии брачно-семейного права КНР (некоторые аспекты). Право и политика. 2017. № 7. C. 48-55. URL: https://nbpublish.com/ library_read_article.php?id=23430. (дата звернення: 03.12.2020).

8. Türk Medeni Kanunu № 4721 (2002) Turkish Civil Code Law. URL: https://www.lexpera. com.tr/mevzuat/kanunlar/turk-medenikanunu-4721 (дата звернення: 03.12.2020).

9. Civil Code of Iran. URL: https://www.wipo. int/edocs/lexdocs/laws/en/ir/ir009en.pdf （дата звернення: 03.12.2020)

10. Ehzas Zar Rokh. Marriage and Divorce Under Iranian Family Law. URL: https:// papers.ssrn.com/sol3/papers.cfm?abstract $\mathrm{id}=1886349 \#: \sim:$ text $=\operatorname{In} \% 20 \mathrm{a} \% 20 \mathrm{muta} \% 2 \overline{0}$ marriage $\% 2 \mathrm{C} \% 20$ the,that $\% 20 \mathrm{a} \% 20 \mathrm{man} \% 20$ may\%20 contract (дата звернення: 03.12.2020).

11. The Indian Trust Act - 1882. URL: https:// www.indiacode.nic.in/handle/123456789/2327? view type $=$ search $\&$ sam handle $=123456789 / 1362$ (дата звернення: 03.12.2020)

12. Suresh \& Co. Family Trusts - An Overview URL: https://www.primeglobal.net/news/familytrusts-an-overview-suresh-co (дата звернення: 03.12.2020).

13. Uniform Trust Code. URL: https:// www.uniformlaws.org/committees/communityhome/librarydocuments? communitykey $=19$ 3ff839-7955-4846-8f3c-ce74ac23938d\&tab=librar ydocuments \&LibraryFolderKey $=\&$ DefaultView $=$ (дата звернення: 03.12.2020)

14. Rose J. What Is a Family Trust and Should You Set One Up? / Jeff Rose. Good financial cents. 2020. URL: https://www.goodfinancialcents.com/ family-trust-benefits-setting-up-trust/ (дата звернення: 03.12.2020).

15. Family trusts - Pros \& cons of setting up a trust. Live sorted. 2020. URL: https://sorted.org.nz/ guides/protecting-wealth/family-trusts/ (дата звернення: 03.12.2020). states

Liliya Radchenko. Family trusts and management of marital property by laws of some foreign

The article is devoted to the peculiarities of regulating the management of marital property under the lawes of different states and legal families, determining the specifics of normative consolidation and implementation of spouses' rights to manage joint property in the law of individual foreign states, and outlining the main legal approaches to foreign legislation. In the research, conclusions and proposals for the improvement and development of the national system of legal regulation of family relations are formulated.

The article, based on a comparative legal analysis of the provisions of regulations of foreign countries in the field of regulation of relations on the management of marital property, emphasizes the existence of several legal approaches. According to the first, which is applied primarily in the countries of the continental legal family, the management of marital property is carried out on the basis of a legal regime providing for joint management of marital property (with certain features defined by the national legislation of the respective states).. In Asian countries, the legal regulation of marital property management is regulated differently, but even today, the family law of many countries in the region is characterized by the informal supremacy of the husband in deciding on the management of joint property. 
According to the approach used in the countries of the American law- the management of marital property is based on a system of family trusts, which provides for the possibility of providing joint property for the management of a third party for the benefit of the spouses or their children. The first approach is dominant in the family legislation of Ukraine, which provides for the management of marital property on the basis of the legal regime. However, the possibility of applying elements of trust management to regulate the relationship of acquisition and management of joint property of the spouses should not be unconditionally denied. At the same time, the implementation of the institution of trust management in family relations should not contradict the legislation of Ukraine, the principles of family law and moral principles of society, as well as satisfy the rights and legitimate interests of spouses in the management of common property.

Key words: joint property, legal regime, contractual regime, family, family relations, trust management, family trust, international family law. 